\title{
HYGIFNE AND PUBLIC HEALTH
}

UNDER THE C:HARGE OF

\author{
EDWARD F. WILIOUGHBY, M.D., . \\ of Lospos; \\ AND
}

CHARLES HARRINGTON, M.D.,

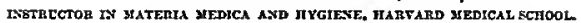

Fhies rivo Disease.

Suboeon-Genenal Sir Wiltian Moore (Mfedical Magazine, July, 1893) regards the dissemination of diseases hy files as a matter looked upon with tro much indifference, und instances an epidemic of nnthrax which was spread hy fies which had covered the carcass of a dog thrown into a ditch in Cortal. He quotes the experiments of Suwtschenko with flies and cholera germs, and ohserves that it is worth noticing that in India it is during the time nnd senson of the grentest prevalence of cholera that fies most ahound. The possihility of flies carrying the organisms of typhoid and phthisis is suggested, and the helief is expressed that leprosy is often conveyed by fies which appear to he pnrticularly fond of lcprous sores and of investigating anything in the way of a sore on a healthy person.

There is no douht that ophthalmia is so spread, and an instance is given of complete destruction of an ege from diphtherial inflammation following a sting in the eye by a fy which had apparently risen from a dunghill. That venerenl disense is not more frequently disseminated hy fies is prohahly expluinahle hy the fact that the sores are usunlly on un exposed parts of the hody.

\section{Action of Cold on Cholera Bacillt.}

As outhresk of cholera occurred in the insnne asylum nt Nietlehen, in the heginning of 1893 , at $\mathbf{n}$ time when the temperature was twenty degrees and more helow zero, Centigrade, nnd all the rivera were frozen. To determine whether the bacilli would die or he preserved in the ice, a series of experiments was undertnken hy Prof. RENe, of Halle (Forlschritte der Mfedicin, Way 15, 1893). Wnter from the Sanle was sterilized, cooled, inocnlated with cholern germs, and frozen; the ice heing finnlly melted, and cultures made. In the first experiment each c.cm. of wnter contained, nfter inoculation, 620,000 organisms. The flask was frozen at $-9.6^{\circ} \mathrm{C}$, and exposed to that temperature thirty-nine hours. The cultures made from the melted ice were negative in results. A second test with more richly inoculated water rept in a freezing mixture of ice and snlt, gave negntive results after one day. Sterilized wnter 80 inoculnted thnt ench cuhic centimetre contained countless hacteria, was frozen, and cnltures made from the melted ice after forty-eight nnd ninety-six hours. After forty-eight hours of exposure each cuhic centimetre of melted ice yielded 24,400 organisms, but after ninety-six hours the 
results were pegatire in each of twelve tests. Experimedts were undertaken with unsterilized Sagle water to determine the influence, if any, of the presence of spaltpilze. A number of hottles of the water so inoculated as to contain 1,483,000 organisms to the cubic ccotimetre were frozen, and on each following day ope bottle was taken, the ice thereis melted and examined, then re-frozen. It wbs foupd that after five dnys of uninterrupted freezing all the bacilli pre killed, nod after six and seven days when the freezing is interrupted. The conclusion is thnt cholera hacilli cannot develop after heing in ice eight days.

UFFELAMAN (Berliner klinische Wochensehrift, 1893, No. 7) bad already begun experiments in the same direction before the outhreak occurred at Nietlehen, and was ahle to utilize the intense cold of January. His results show that cholern hacilli have considerahle power to withstand cold gnd thpt they succumb only after a certain time, the duration of vitality heing seemingly dependent on the degree of cold. There seems to he po essential difference in the hehavior of entirely fresh or older cultures of the hacilli.

\section{DIPHTHERIA IN LOMBABDY.}

Dr. Frasico Mirsag lia (Giornale della Reale Socield Haliana d' Igiene, July. 1893), reporting the results of his investigation of an outbreak of diphtheria in Somm 0, Lombardy, during the summer and autumn of 1892, states that the spread of the disesse is largely due to the prejudices of the peoplc, who conceal sickness, disohey the physician, and throw away his medicines. Among other circurnstances highly favorahle to the spread of the disease, he mentions the direct contact of children, who, living in common, easily transmit the infecting bacillus; the indirect contact hy means of mothers, of female neighhors, and of domestic utensils; the spitting on the foor, or on sheets and counterpnnes not subsequently washed; insuficient means of disinfection; washing of clothes of the infected in water which afterward becomes a focus of disease: shsence of cleanliness; nnd bnd dripking-winter.

\section{LEPROSY IN INDIA.}

THE copclusions of the Leprosy Commission (Indian Afedico-Chirurgical Review, July, 1893) are that leprosy is a disease sui generis, not diffused by bereditary transmission; it must be regarded as contagious and inoculable, yet the extent to which it is propagated by these menps is exceedingly small. It is not directly originated by the use of any particular article of food, nor by nny climatic or telluric conditions, nor by insanitary surroundings; Deither does it nffect nny rnce or caste. It is indirectly influenced by insanitary surroundings, such as poverty, hpd food, nod deficient drainge and ventilation, which eause a predisposition and increase the susceptihility of the individual. In the great majority of eases, it originates from a sequence of concurrence of causes and conditions related to each other in ways imperfectly known. Complete segregation has never yet heen possihle; in Indin it is phsolutely impracticable. The commission are of opinion that the sale of articles of food and drink hy lepers should be prohihited, and that they should he prevented from practising prostitution, and from following such occupations as those of harher and washerman. 